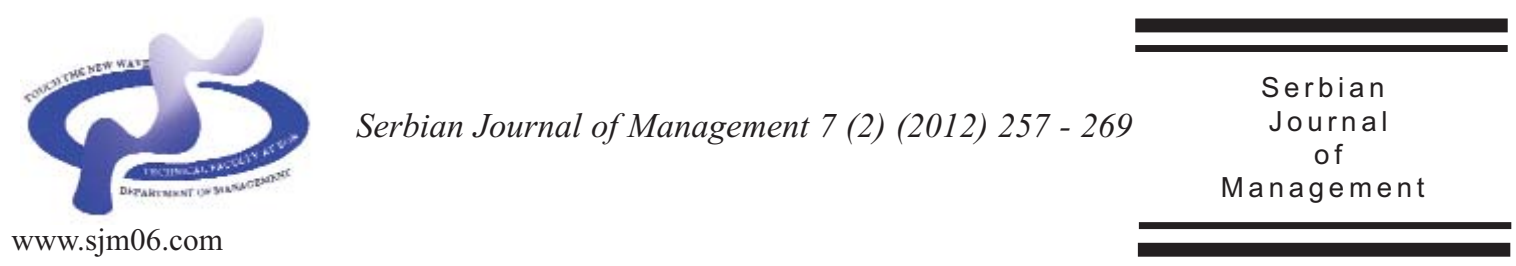

\title{
INVESTMENT PROJECT SELECTION BY APPLYING COPRAS METHOD AND IMPRECISE DATA
}

\author{
Gabrijela Popovič*, Dragiša Stanujkić and Sanja Stojanović \\ Faculty of Management Zaječar, Megatrend University Belgrade \\ Park Šuma “Kraljevica” bb, 19000 Zaječar, Serbia
}

(Received 16 July 2012; accepted 27 September 2012)

\begin{abstract}
Investment projects can have a significant impact on the functioning and development of a company. Therefore, the selection of one or more investment projects from the set of possible is an important and difficult task for decision makers. This paper considers the investment projects selection based on financial analysis criteria and use of imprecise data. In the proposed model, the alternative projects performances are expressed using crisp and interval values, and then the best project from the available is selected by using COPRAS and COPRAS-G methods. A numerical example is given to demonstrate the applicability and effectiveness of the proposed approach.
\end{abstract}

Keywords: Multi-criteria, investment project, imprecise data, interval data, COPRAS, COPRAS-G.

\section{INTRODUCTION}

Investment projects are activities where companies spend their capital resources in order to create a producing asset from which they expect to realize benefits over an extended period of time. In order to decide which of the proposed investment projects should be selected, a various elements may be taken into account. The efficiency of investment projects can be evaluated by using economic, financial, technological, ecological-environmental and other efficiency indicators (Simanauskas \& Sidlauskas, 2006) but it is evident that many companies prefer to concentrate on establishing the financial viability of projects.

The investment project selection among a set of possible alternatives is a very difficult

\footnotetext{
* Corresponding author: gabrijela.popovic@fmz.edu.rs

DOI: $10.5937 /$ sjm 7-2268
} 
task for decision makers (DM), because they have to face with constrains that could affect on the realization of the project in the future. According to info-tech research group (2008), the project must be completed under three basic constrains, and they are:

- $\quad$ scope - project size

- time - time framework available for completing the project

- costs (budget) - amount of money disposable for project funding

These constrains are in direct conflict with each other, and changing one of them have direct impact on the others. Simpler case of mutually exclusive projects selection is considered in this paper.

Over time, various approaches have been proposed for evaluation of projects such as: goal programming (Santhanam \& Kyprasis, 1995; Oliveria et al., 2003), zero-one programming (Regan \& Holtzman, 1995; Mavrotas et al., 2003), techniques based on the utility function (Graves \& Rinquest, 1996; Wong et al., 2000).

During the selection of investment projects, DM usually make a choice between several available alternative projects based on certain criteria (attributes), because the selection of investment projects can be considered as a multi-criteria decisionmaking problem. Therefore, many authors propose the use of multi-criteria decision making (MCDM) methods for selection of the most suitable project (Obradović, 2012).

Authors have considered investment project selection as important part of decision making process in the corporations. Weingartner (1966) showed criteria for programming investment project selection. Tzeng and Teng $(1993,1998)$ presented transportation investment project selection with fuzzy multiobjectives. Dimova et al. (2006) used MCDM in a fuzzy setting to develop the investment projects assessment application. Various authors propose the use of ELECTRE method (Costa et al., 2003; Mavrotos et al., 2003) for solving project evaluation problems. AHP method has been also used by many authors to resolve decision-making issues in project selection (Mian \& Christine, 1999; Dey \& Gupta, 2001). Application of different MCDM methods (TOPSIS, SAW, COPRAS) for analysis of investments projects in construction are proposed by Ustinovichius et al. (2007). In addition, the application of different MCDM methods for solving some problems related to construction projects are proposed by Zavadskas et al. (2008c; 2008d; 2010).

The use of classical MCDM methods requires the use of crisp (precise) data, i.e. the performance ratings of alternatives and criterion weights must be precisely determined. However, solving many realworld problems often requires some kind of prediction, and then it is not possible to precisely determine the data which are necessary for using the classical MCDM methods. Therefore, many MCDM methods have their extensions, formed with the aim of their application in case of imprecise data use.

One of the MCDM methods that have their extensions is COPRAS method. For its application in the case of data expressed in the form of intervals, its extended version COPRAS-G method was established, and also COPRAS-F for applying fuzzy sets.

But many real-world problems cannot be strictly classified into two categories: a category of problems that provides use of crisp data and a category that does not allow its use. In fact, solving many real-world problems using MCDM methods often requires the simultaneous use of crisp and 
imprecise - fuzzy data. Therefore, we suggest finding and using extended form of procedures that allow mixed use of the steps applied in classical and steps applied in the modified versions of MCDM methods, which are formed with the aim of using data represented as fuzzy numbers or intervals.

The rest of this paper is organized as follows: Section 2 considers some important financial criteria for projects evaluation. In section 3, COPRAS and GOPRAS-G method is presented. In section 4 , a numerical example is presented to illustrate the applicability and efficiency of the proposed methodology. Finally, the concluding remarks are given in Section 5.

\section{CRITERIA FOR DETERMINING} PROJECTS FINANCIAL FEASIBILITY

In literature several alternate criteria for financial evaluation of investment projects are discussed (Remer et al., 1993; Lefley \& Morgan, 1998; Nowak, 2005; Biezma \& San Cristobal, 2006). In this section, we will describe some of the most important, such as:

- Pay Back Period,

- Net Present Value,

- Internal Rate of Return, and

- $\quad$ Profitability Index.

Pay Back Period (PBP) represents the number of years required for an investment project to pay itself off, from annual revenues that it generates. When the projected annual net cash flow is uniform, $P B P$ is calculated as:

$P B P=\frac{A_{0}}{F}$

where $A_{0}$ is the initial cash investment, i.e. cost of the investment, and $F$ is the projected average annual net cash flow from the investment.

The $P B P$ is probably the simplest form of financial analysis. The use of the $P B P$ as investment decision rule specifies that all projects with a $P B P$ less than a specified number of years are acceptable, and investment with the shortest $P B P$ is the most acceptable.

Net Present Value (NPV) is a difference between the present value of the future net cash flows and the initial cash investment. When the annual net cash flow is uniform, $N P V$ is calculated using the following formula:

$$
N P V=A_{0}+\sum_{t=1}^{T} \frac{F_{t}}{(1+k)^{t}}
$$

where $F_{t}$ is the net cash flow in period $t, k$ is the required rate of return, and $T$ is number of years in the project (investment's expected life).

The $N P V$ is generally considered as one of the most important criteria of projects evaluation.

The use of the NPV as investment decision rule specifies that all projects with a positive $N P V$ are profitable, i.e. feasible, and project with higher $N P V$ is the most acceptable.

In order to include the impact of inflation, or deflation, the formula (2) can be written as follows:

$$
N P V=A_{0}+\sum_{t=1}^{T} \frac{F_{t}}{\left(1+k+p_{t}\right)^{t}}
$$

where $p_{t}$ is the estimated rate of inflation, or deflation, during period $t$.

Internal Rate of Return (IRR) is a discount rate that makes the present value of the future net cash flows equal to the initial cash investment. It can be calculated using the 
following formula:

$\sum_{t=1}^{T} \frac{F_{t}}{(1+I R R)^{t}}-A_{0}=0$

The IRR is also considered as very important criteria of projects evaluation. A project is acceptable for investment when the $I R R$ is higher than the required rate of return, and investment with higher $I R R$ is the most acceptable.

Profitability index (PI), also known as the Benefit Cost Ratio $(B C R)$, is the ratio between the discounted value of future net cash flows and initial cash investment. It can be calculated using the following formula:

$P I=\frac{\sum_{t=1}^{T} \frac{C F_{t}}{(1+k)^{t}}}{A_{0}}$

The $P I$ is also considered as important criteria of projects evaluation, because it can provide a measure of relative efficiency among similar projects. As investment decision rule the investment project is acceptable when the $P I$ is greater than 1 , and investment with higher $P I$ is the most acceptable.

In order to include the impact of inflation the formula (5) can be written as follows:

$P I=\frac{\sum_{t=1}^{T} \frac{C F_{t}}{\left(1+k+p_{t}\right)^{t}}}{A_{0}}$

3. RANKING THE ALTERNATIVES APPLYING COPRAS AND COPRAS-G METHOD

A method of complex proportional evaluation known as COPRAS (COmplex PRoportional ASsessment) method is presented by Zavadskas and Kaklauskas
(Zavadskas et al., 1994). This method is useful for value evaluation of maximizing as well as minimizing criteria. Description of COPRAS methods and possibilities of its application are published in a large number of papers (Zavadskas et al., 2001; Vilutiene \& Zavadskas, 2003; Zavadskas et al., 2004; Kaklauskas et al., 2005; Kaklauskas et al., 2006; Zavadskas et al., 2008b).

\subsection{Common COPRAS method}

Ranking alternatives by the COPRAS method assumes direct and proportional dependence of significance and priority of investigated alternatives on a system of criteria (Ustinovichius et al. 2007). The determination of significance and priority of alternatives, by using COPRAS method, can be expressed concisely using four stages (Ustinovichius et al., 2007; Viteikiene and Zavadskas, 2007):

Stage 1. The normalized decision-making matrix D is constructed. In MCDM process, criteria usually have different units of measure. In order to transform performances of considered alternatives into comparable dimensionless values, normalization procedure is used. An overview of some of the most important multi-criteria methods, and their normalization procedures, is shown in Ginevicius (2007). A detailed overview of the most important normalization procedures are also discussed in Zavadskas et. al. (2008a).

For normalization in COPRAS method the following formula is used:

$$
\tilde{x}_{i j}=\frac{x_{i j}}{\sum_{i=1}^{m} x_{i j}}
$$

where $x_{i j}$ is the performance of the $i$-th alternative with respect to the $j$-th criterion, 
$\tilde{x}_{i j}$ is its normalized value, and $m$ is number of alternatives.

Stage 2. The sums of weighed normalized criteria describing the $i$-th alternative are calculated. In COPRAS method, each alternative is described with its sums of maximizing attributes $S_{+i}$, i.e. optimization direction is maximization, and minimizing criteria $S_{-i}$, i.e. optimization direction is minimization.

In order to simplify calculation of $S_{+i}$ and $S_{-i}$ in the decision-making matrix columns first of all are placed maximizing criteria and then minimizing criteria. In such cases, $S_{+i}$ and $S_{-i}$ is calculated as follows:

$S_{+i}=\sum_{j=1}^{k} \widetilde{x}_{i j} \cdot q_{j}$

$S_{-i}=\sum_{j=k+1}^{n} \widetilde{x}_{i j} \cdot q_{j}$

In formulae (8) and (9), $k$ is number of maximizing criteria; $n$ is total number of criteria; and $q_{j}$ is significance of the $j$-th criterion.

Stage 3. Calculation of the relative weight of each alternative. The relative weight $Q_{i}$ of $i$-th alternative is calculated as follows:

$$
Q_{i}=S_{+i}+\frac{\min _{i} S_{-i} \sum_{i=1}^{m} S_{-i}}{S_{-i} \sum_{i=1}^{m} \frac{\min _{i} S_{-i}}{S_{-i}}}
$$

Formula (10) can also be written in simplified form as follows:

$$
Q_{i}=S_{+i}+\frac{\sum_{i=1}^{m} S_{-i}}{S_{-i} \sum_{i=1}^{m} \frac{1}{S_{-i}}}
$$

Stage 4. Determine the priority order of alternatives. The priority order of compared alternatives is determined on the basis of their relative weight. The alternative with higher relative weight has higher priority (rank), and the alternative with the highest relative weight is the most acceptable alternative.

$$
A^{*}=\left\{A_{i} \mid \max _{i} Q_{i}\right\}
$$

The presented procedure of COPRAS method indicates that it can be easily applied for evaluating the alternatives and selecting the most efficient one, with decision maker being completely aware of the physical meaning of the process (Ustinovichius et al., 2007).

However, many decisions are made in real-world situations where criterion values are not precisely known. Then criterion values can be expressed in the form of intervals (Zavadskas et al., 2008b; Zavadskas et al., 2009). For this reason a new method of multiple-criteria complex proportional assessment with values determined in intervals - COPRAS-G is developed (Zavadskas et al., 2008b).

\subsection{COPRAS-G method}

Instead of using crisp values, COPRAS-G uses criterion values determined in intervals. Replacement of the crisp $x_{i j}$ with the interval value $\left[\underline{x}_{i j}, \bar{x}_{i j}\right]$, where $x_{i j}$ is the lower limit and $x_{i j}$ is the upper limit of interval, requires some modifications in the ranking procedure, which manifest themselves in stage 1 and stage 2 of the previously described procedure.

In stage 1, the use of intervals has effects on the normalization of criterion values. The normalized values of decision-making matrix whose elements are intervals are 
calculated as follows (Zavadskas et al., 2008b; Hwang and Yoon, 1981):

$$
\begin{gathered}
\tilde{\underline{x}}_{i j}=\frac{\underline{x}_{i j}}{\frac{1}{2}\left(\sum_{i=1}^{m} \underline{x}_{i j}+\sum_{i=1}^{m} \bar{x}_{i j}\right)}=\frac{2 \underline{x}_{i j}}{\sum_{i=1}^{m} \underline{x}_{i j}+\sum_{i=1}^{m} \bar{x}_{i j}} \\
\widetilde{\bar{x}}_{i j}=\frac{\bar{x}_{i j}}{\frac{1}{2}\left(\sum_{i=1}^{m} \underline{x}_{i j}+\sum_{i=1}^{m} \bar{x}_{i j}\right)}=\frac{2 \bar{x}_{i j}}{\sum_{i=1}^{m}\left(\underline{x}_{i j}+\bar{x}_{i j}\right)}
\end{gathered}
$$

In formulae (13) and (14), $\underline{x}_{i j}$ and $\bar{x}_{i j}$ are the lowest and highest performance of the $i$ th alternative with respect to the $j$-th attribute; and $\underline{\tilde{x}}_{i j}$ and $\tilde{\bar{x}}_{i j}$ are its normalized values.

In stage 2, the use of intervals has impact on formulas used for calculation of $S_{+i}$ and $S_{-i}$. Then, the sum of maximizing attributes $S_{+i}$ of $i$-th alternative is calculated as:

$S_{+i}=\frac{1}{2} \sum_{j=1}^{k}\left(\underline{\widetilde{x}}_{i j}+\widetilde{\widetilde{x}}_{i j}\right) \cdot q_{j}$

and the sum of minimizing criteria $S_{-i}$ are calculated as follows:

$$
S_{-i}=\frac{1}{2} \sum_{j=k+1}^{n}\left(\tilde{\widetilde{x}}_{i j}+\widetilde{\bar{x}}_{i j}\right) \cdot q_{j}
$$

\subsection{Detailed procedure for ranking alternatives by COPRAS method, when criterion values are expressed using crisp or interval numbers}

The detailed procedure for ranking alternatives using COPRAS or COPRAS-G method is shown in (Zavadskas et al., 2008b; Zavadskas et al., 2009).

In this section we will show the detailed procedure for determining the most acceptable alternative when criterion values are expressed with combined use of crisp and interval numbers. This procedure can be accurately expressed in the following steps:

Stage 1. Selecting the set of the most important criteria, describing the alternatives. The purpose of this phase is to identify the available alternatives and criteria that will be used for their evaluation. Performance ratings of alternatives with respect to chosen criteria also can be determined in this phase.

As a result of performing these activities decision-making matrix can be formed.

Stage 2. Constructing the decisionmaking matrix. For the MCDM problem that simultaneously uses the criteria with crisp values and criteria with values expressed in intervals, decision matrix can be expressed as follows:

$X=\left[\begin{array}{ccccc}x_{11} & \cdots & {\left[\underline{x}_{1 j}, \bar{x}_{1 j}\right]} & \cdots & x_{1 n} \\ x_{21} & \cdots & {\left[\underline{x}_{2 j}, \bar{x}_{2 j}\right]} & \cdots & x_{2 n} \\ \vdots & \cdots & \vdots & \cdots & \vdots \\ x_{m 1} & \cdots & {\left[\underline{x}_{m j}, \bar{x}_{m j}\right]} & \cdots & x_{m n}\end{array}\right]$

where $x_{i j}$ is performance of $i$-th alternative with respect to $j$-th criterion, $m$ is number of alternatives and $n$ is number of criteria. For criteria which performance is determined in intervals $x_{i j}$ it is determined by its: $\underline{x}_{i j}$ - the lower limit and $\bar{x}_{i j}$ - the upper limit.

Stage 3. Normalizing the decision-making matrix. The normalized values of decisionmaking matrix are calculated using formula (7) for criteria with crisp values and using (13) and (14) for criteria with values expressed in intervals.

Stage 4. Determining the criteria weights. The procedure of determining the criterion weight is usually not an integral part of many significant multi-criteria decision-making methods. However, the criterion weight may 
significantly affect to the obtained results and that's why different authors suggest different techniques (Ma et al., 1999), such as pair-wise comparisons (Saaty, 1977), Delphi method (Hwang and Lin, 1987) and Entropy approach (Hwang and Yoon, 1981).

Stage 5. Calculate sums of maximizing criteria, for each alternative. When the decision-making matrix contains criteria with crisp and criteria whose values are expressed in intervals, the sums of maximizing criteria can be calculated using the following formula:

$S_{+i}=S_{+i}^{c}+S_{+i}^{g}$

In formula (18) $S_{+i}^{c}$ is the sum of maximizing criteria with crisp values of $i$-th alternative, calculated using formula (8), and $S_{+i}^{g}$ is the sum of maximizing criteria with values are expressed in intervals, calculated using formula (15).

Stage 6. Calculate sums of minimizing criteria, for each alternative. Similar to the previous, the sums of minimizing criteria are calculated using the following formula:

$$
S_{-i}=S_{-i}^{c}+S_{-i}^{g}
$$

In formula (19) the sums of minimizing criteria with crisp values $S_{-i}^{c}$ are calculated using formula (9) and sums of minimizing criteria with values expressed in intervals $S_{-i}^{g}$ using formula (16).

Stage 7. Calculating the relative weight $Q_{i}$ of each alternative, by using formula (11).

Stage 8. Determining the priority order of alternatives. The priority order of alternatives is determined on the basis of their relative weight, and alternatives with higher relative weight have a higher rank.

Stage 9. Determining the most acceptable alternative, by using formula (12).
As can be concluded, the proposed procedure is still easy to use and logically understandable to decision makers.

\section{NUMERICAL EXAMPLE}

Suppose that decision makers want to choose the most acceptable investment project from four available. They want to choose a project which will:

- $\quad$ ensure higher profit from investment;

- ensure a higher ratio between future expected net flows and initial investment;

- ensure as quickly as possible recover of initial investment; and

- be realized with the least risk.

In order to determine the achievement of the requirements, we suggest the use of the following financial indicators:

- $\quad N P V$ for the value of profit realized from investment;

- $\quad P I$ for ratio between future expected net flows and initial investment; and

- $\quad P B P$ for period of time required for an investment to pay itself off.

Investments as well as other projects are characterized by certain forms of risk. Some assessment of financial risk can be achieved by using $P B P$ and $I R R$ indicators, i.e. project with a lower value of $P B P$ or greater value $I R R$ has less financial risk. Many other forms of possible risks are often presented using aggregate indicators that are assigned to each project.

Based on previous considerations, we conclude that we have the following criteria on which we can make a selection of investment projects: $N P V, I R R, P I, P B P$, and Risk. Attributes $N P V, I R R$, and $P I$ are maximizing criteria, while the remaining criteria, $P B$ and Risk, are minimizing criteria. In addition, criteria $N P V$ and $P I$ have 
the values that belong to closed intervals, while other criteria have crisp values.

Input characteristic of available project are shown in Table 1.

Table 1. Raw data

\begin{tabular}{|l|c|c|c|}
\hline Project & $\begin{array}{c}\text { Initial } \\
\text { Investment }\end{array}$ & $\begin{array}{c}\text { Expected } \\
\text { Annual } \\
\text { Profit }\end{array}$ & Years \\
\hline & $C F_{0}$ & $C F$ & $T$ \\
\hline Project $\mathrm{A}$ & 140 & 35 & 7 \\
\hline Project $\mathrm{B}$ & 200 & 50 & 6 \\
\hline Project $\mathrm{C}$ & 170 & 40 & 8 \\
\hline Project D & 250 & 50 & 10 \\
\hline
\end{tabular}

Suppose that the required discount rate for all projects is $5.0 \%$, and because it is not possible to accurately predict the future rate of inflation, which is why DM estimated that it can move between 2.5 to $5.5 \%$. Suppose also that the DM, using values shown in Table 2, for each project, assign the appropriate risk factor which includes other, non-financial, aspects of project implementation risks.

Table 2. Levels of project risk

\begin{tabular}{|l|c|}
\hline Risk level of projects & Quantitative value \\
\hline no risk & 0 \\
\hline extremely low level of risk & 1 \\
\hline low level of risk & 3 \\
\hline intermediate level of risk & 5 \\
\hline higher level of risk & 7 \\
\hline very high level of risk & 9 \\
\hline extremely high level of risk & 10 \\
\hline
\end{tabular}

Table 3. Initial decision making matrix

And finally, initial decision-making matrix used for the selection of investment projects is shown in Table 3, whose values of columns: $N P V, I R R, P I$, and $P B P$ are obtained using the formulae (3), (4), (6) and (1), and values of column Risk are obtained based on the preference of DM. Values of $N P V$ and $P I$ are expressed in intervals.

Normalization procedure is used because criteria have different units of measure. Using formula (7) for crisp and (13) and (14) for values expressed in intervals normalized decision-making matrix, shown in Table 4, are formed.

Then, by multiplying elements of normalized decision-making matrix with significance to appropriate criteria weighted normalized decision-making matrix, shown in Table 5, are formed.

Calculation of $S_{+i}$ and $S_{-i}$ is obtained by using formulae (8) and (9) for crisp values and (15) and (16) for intervals. The relative weight of each alternative is calculated using formula (11). Using formula (12) the most acceptable alternative is determined. Ranking order is obtained according to relative weight where alternative with higher relative weight have the primate. Final results of projects evaluation are shown in Table 6.

As can be seen from Table 6, the best investment project selected is project $\mathrm{C}$,

\begin{tabular}{|c|c|c|c|c|c|c|c|}
\hline Criteria & \multicolumn{2}{|c|}{$\boldsymbol{I P V}$} & $\boldsymbol{I R R}$ & \multicolumn{2}{c|}{$\boldsymbol{P I}$} & $\boldsymbol{P B P}$ & $\boldsymbol{R}$ isk \\
\hline & \multicolumn{2}{|c|}{$\epsilon$} & $\%$ & \multicolumn{2}{c|}{$\%$} & Year & \\
\hline Optimization & \multicolumn{2}{|c|}{$\max$} & $\max$ & \multicolumn{2}{|c|}{$\max$} & $\min$ & $\min$ \\
\hline$q_{j}$ & \multicolumn{2}{|c|}{0.45} & 0.21 & \multicolumn{2}{c|}{0.11} & 0.12 & 0.11 \\
\hline & \multicolumn{2}{|c|}{$\boldsymbol{C}_{\mathbf{1}}$} & $\boldsymbol{C}_{\mathbf{2}}$ & \multicolumn{2}{c|}{$\boldsymbol{C}_{\mathbf{3}}$} & $\boldsymbol{C}_{\mathbf{4}}$ & $\boldsymbol{C}_{\mathbf{5}}$ \\
\hline Project & $\underline{x}_{i 1}$ & $\bar{x}_{i 1}$ & & $\underline{x}_{i 3}$ & $\bar{x}_{i 3}$ & & \\
\hline $\boldsymbol{A}$ & 27.63 & 45.38 & $16.33 \%$ & 1.20 & 1.32 & 4.0 & 3 \\
\hline $\boldsymbol{B}$ & 14.61 & 34.69 & $12.98 \%$ & 1.07 & 1.17 & 4.0 & 5 \\
\hline $\boldsymbol{C}$ & 29.09 & 52.58 & $15.09 \%$ & 1.17 & 1.31 & 4.5 & 3 \\
\hline $\boldsymbol{D}$ & 13.41 & 41.31 & $12.13 \%$ & 1.05 & 1.17 & 4.5 & 7 \\
\hline
\end{tabular}

* NPV data in $10,000 €$ 
which has the highest relative weight of very important in project's assessment is: 0.291 . worth and riskiness. Zwikael and Smyrk

Table 4. Normalized decision-making matrix

\begin{tabular}{|c|c|c|c|c|c|c|c|}
\hline \multirow{2}{*}{ Project } & \multicolumn{2}{|c|}{$\boldsymbol{C}_{\mathbf{1}}$} & $\boldsymbol{C}_{\mathbf{2}}$ & \multicolumn{2}{|c|}{$\boldsymbol{C}_{\mathbf{3}}$} & $\boldsymbol{C}_{\mathbf{4}}$ & $\boldsymbol{C}_{\mathbf{5}}$ \\
\cline { 2 - 8 } & $w_{1}$ & $b_{1}$ & & $w_{3}$ & $b_{3}$ & & \\
\hline $\boldsymbol{A}$ & 0.214 & 0.351 & 0.289 & 0.253 & 0.280 & 0.235 & 0.167 \\
\hline $\boldsymbol{B}$ & 0.113 & 0.268 & 0.230 & 0.227 & 0.248 & 0.235 & 0.278 \\
\hline $\boldsymbol{C}$ & 0.225 & 0.406 & 0.267 & 0.247 & 0.277 & 0.263 & 0.167 \\
\hline $\boldsymbol{D}$ & 0.104 & 0.319 & 0.215 & 0.223 & 0.246 & 0.267 & 0.389 \\
\hline
\end{tabular}

Table 5. Weighted normalized decision-making matrix

\begin{tabular}{|c|c|c|c|c|c|c|c|}
\hline \multirow{2}{*}{ Project } & \multicolumn{2}{|c|}{$\boldsymbol{C}_{\mathbf{1}}$} & $\boldsymbol{C}_{\mathbf{2}}$ & \multicolumn{2}{c|}{$\boldsymbol{C}_{\mathbf{3}}$} & $\boldsymbol{C}_{\mathbf{4}}$ & $\boldsymbol{C}_{\mathbf{5}}$ \\
\cline { 2 - 8 } & $w_{1}$ & $b_{1}$ & & $w_{3}$ & $b_{3}$ & & \\
\hline $\boldsymbol{A}$ & 0.096 & 0.158 & 0.061 & 0.028 & 0.031 & 0.028 & 0.018 \\
\hline $\boldsymbol{B}$ & 0.051 & 0.121 & 0.048 & 0.025 & 0.027 & 0.028 & 0.031 \\
\hline $\boldsymbol{C}$ & 0.101 & 0.183 & 0.056 & 0.027 & 0.030 & 0.032 & 0.018 \\
\hline $\boldsymbol{D}$ & 0.047 & 0.144 & 0.045 & 0.024 & 0.027 & 0.032 & 0.043 \\
\hline
\end{tabular}

Table 6. Final results of ranking, provided by applying COPRAS and COPRAS-G method

\begin{tabular}{|c|c|c|c|c|c|c|c|c|}
\hline \multirow{2}{*}{ Project } & \multicolumn{3}{|c|}{$\boldsymbol{S}_{+i}$} & \multicolumn{3}{c|}{$\boldsymbol{S}_{\boldsymbol{i}}$} & $\boldsymbol{Q}_{\boldsymbol{i}}$ & Rank \\
\cline { 2 - 10 } & Crisp & Interval & $\boldsymbol{\Sigma}$ & Crisp & Interval & $\boldsymbol{\Sigma}$ & & \\
\hline $\boldsymbol{A}$ & 0.061 & 0.156 & 0.217 & 0.047 & 0.0 & 0.047 & 0.286 & 2 \\
\hline $\boldsymbol{B}$ & 0.048 & 0.112 & 0.160 & 0.059 & 0.0 & 0.059 & 0.215 & 3 \\
\hline $\boldsymbol{C}$ & 0.056 & 0.171 & 0.227 & 0.050 & 0.0 & 0.050 & 0.291 & 1 \\
\hline $\boldsymbol{D}$ & 0.045 & 0.121 & 0.166 & 0.075 & 0.0 & 0.075 & 0.209 & 4 \\
\hline
\end{tabular}

Making a decision about investment (2012) suggested novel way of analyzing projects is very complicate task for DM who investment in projects called Project must ask himself if conducted investment Investment Evaluation or PIE model (See will be succesfull. Two variables, which are Figure 1.).

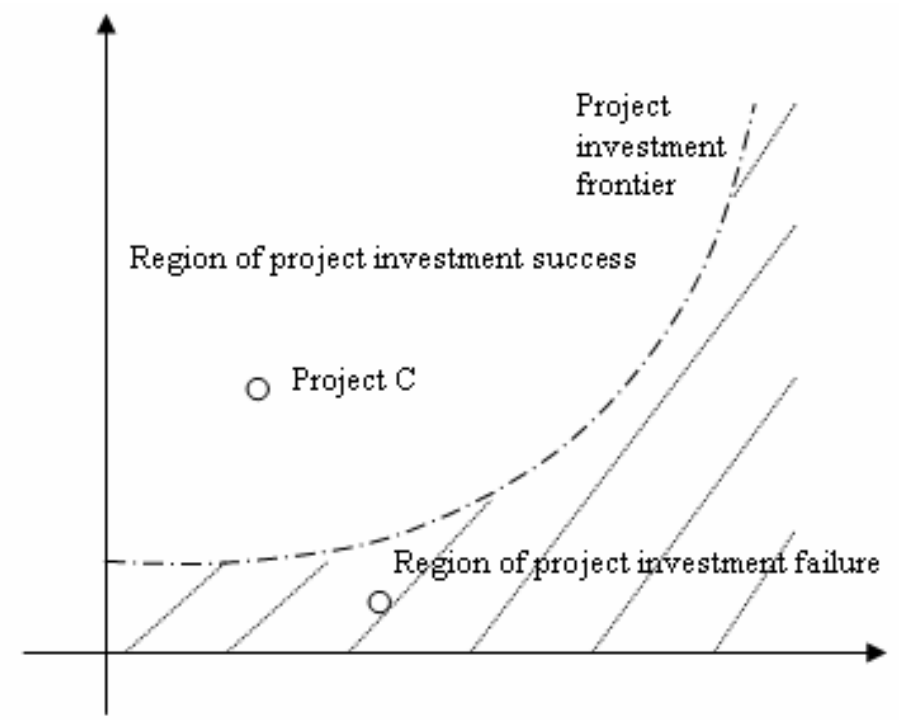

Figure 1. The PIE model for analysis of project investment success (Zwikael and Smyrk, 2011) 
As Figure 1 shows, combinations of worth and risk exposure that lie left and above of project investment frontier, represent projects that are acceptable for investing, while the others which are lying below that frontier are not acceptable because they represent failures.

In order to determine whether gained result is appropriate it is compared with above mentioned PIE model. Final results of conducted procedure, which are shown the project $\mathrm{C}$ as the best ranked project, concur with above assumptions because financial indicators are satisfactory and this project is exposed to the least risk which means that worth and risk combination of project $\mathrm{C}$ lies above project investment frontier represented on Figure 1.

\section{CONCLUSION}

In the case of investment ranking, as well as other types of projects, it is necessary to consider the impact of multiple-criteria, which usually have different significance. COPRAS method provides an effective and understandable procedure for such purposes.

However, the ranking of investment projects also includes a prediction of future outcomes of projects. Such estimated outcomes, cannot be adequately expressed using crisp values.

Expression of imprecise data can be done much more adequately using some form of fuzzy numbers or intervals. However, the use of other forms to represent the values of criteria, such as values expressed in intervals, requires some modification of the classic MCDM methods, or more accurately requires modification of their procedures that are used to determine the overall performance of alternatives. As a result, new methods of multiple-criteria complex proportional assessment with values determined in intervals - COPRAS-G is developed.

However, many real MCDM problems often involve the combined use of criteria with crisp values and criteria values expressed in the form of intervals. To avoid the transformation of crisp in the interval values, which is necessary in case of using COPRAS-G method, we propose a procedure that provides a combined application of crisp and interval values.

The proposed procedure, which can be concluded from the discussed examples, is still simple and effective, as in COPRAS and COPRAS-G methods. The proposed procedure for determining the overall performance of alternatives and their significance also remains understandable to DM.

In addition to the ranking of investment projects, many other real MCDM problems require the combined use of crisp and interval values. The proposed procedure can also be applied in such cases.

Problem connected to use of COPRAS and other MCDM methods is reflected in subjectivity associated with determining the weights of criteria. Also, determining the level of project risk is very complex and debatable and depends on experience of DM. Project realization takes place in an open environment and it is exposed to market, political and social changes that affect on the risk level. Because the investment projects are durable, risk level that is determined at the start, can change during the project realization.

Investment project selection is very important issue because it can contribute to the corporate success or can have disastrous results and deserves special attention. Use of 
scientific methods in that case is necessary in order of achieving a certain level of the decisions reliability. Subjectivity elimination is of very great importance as well as properly determining of the risk level.

\title{
СЕЛЕКЦИЈА ИНВЕСТИЦИОНИХ ПРОЈЕКАТА ПРИМЕНОМ “COPRAS" МЕТОДЕ ЗА НЕПРЕЦИЗНЕ ПОДАТАКЕ
}

\author{
Габријела Поповић, Драгиша Станујкић, Сања Стојановић
}

\section{Извод}

Инвестициони пројекти могу имати значајан утицај на функционисање и развој компаније. Из тог разлога, избор једног или више инвестиционих пројеката из сета већег броја могућности, је важан али тежак задатак за доносиоце одлука. Овај рад разматра селекцију инвестиционих пројеката засновану на критеријумима финансијске анализе и употребе непрецизних података. У предложеном моделу, алтернативне перформасе пројеката су представљене преко сирових интервалних података, а потом је најболја опција пројекта одабрана употребом "COPRAS" и “COPRAS-G" метода. Дат је и нумерички пример који демонстрира примењивост и ефективност предложеног приступа.

Кључне речи: Вишекритеријумска анализа, инвестициони пројекти, непрецизни подаци, интервални подаци, COPRAS, COPRAS-G.

\section{References}

Biezma, M.V., \& San Cristobal, J.R. (2006). Investment criteria for the selection of cogeneration plants - a state of the art review. Applied Thermal Engineering, 26(56): 583-588.

Costa, J.P., Melo, P., Godinho, P., \& Dias, L.C. (2003). The AGAP system: A GDSS for project analysis and evaluation. European Journal of Operational Research, 145(2): 287-303.

Dey, P.K., \& Gupta, S.S. (2001). Feasibility analysis of cross country pipeline projects: A quantitative approach. Project Management Journal, 32(4): 50-58.

Dimova, L., Sevastianov, P., \& Sevastianov, D. (2006). MCDM in a fuzzy setting: Investment projects assessment application. International Journal of Production Economics, 100(1): 10-29.

Ginevicius, R. (2008). Normalization of quantities of various dimensions. Journal of Business Economics and Management, 9(1): 79-86.

Graves, S.B., \& Ringuest, J.L. (1996). Evaluating a portfolio of R\&D investments. High Technology Management Research. 7(1): 53-60.

Group of authors. (2008). Technology insight. Project management: back to basics. Info-tech research group.

Hwang, C.L., \& Lin, M.J. (1987). Group Decision Making Under Multiple Criteria: Methods and Applications. Springer-Verlag, Berlin.

Hwang, C.L. and Yoon, K. (1981). Multiple attribute decision making: Methods 
and applications. Berlin: Springer Verlag.

Kaklauskas, A., Zavadskas, E.K., \& Raslanas, S. (2005). Multivariant design and multiple criteria analysis of building refurbishments. Energy and Buildings, 37(4): 361-372.

Kaklauskas, A., Zavadskas, E.K., Raslanas, S., Ginevicius, R., Komka, A., \& Malinauskas, P. (2006). Selection of low-e windows in retrofit of public buildings by applying multiple criteria method COPRAS: A Lithuanian case. Energy and Buildings, 38(5): 454-462.

Lefley, F., \& Morgan, M. (1998). A new pragmatic approach to capital investment appraisal: The financial appraisal profile (FAP) model. International Journal of Production Economics, 55(3): 321-341.

Lockett, G., \& Stratford, M. (1987). Ranking of research projects, experiments with two methods. Omega, 15: 395-400.

Ma, J., Fan, Z.P., \& Huang, L.H. (1999). A subjective and objective integrated approach to determine attribute weights. European Journal of Operational Research, 112(2): 397-404.

Mavrotas, G., Diakoulaki, D., \& Caloghirou, Y. (2006). Project prioritization under policy restrictions: A combination of MCDA with 0-1 programming. European Journal of Operational Research, 171(1): 296-308.

Mian, S.A., \& Christine, N.D. (1999). Decision-making over the project life cycle: An analytical hierarchy approach. Project Management Journal, 30(1): 40-52.

Nowak, M. (2005). Investment projects evaluation by simulation and multiple criteria decision aiding procedure. Journal of civil engineering and management, 11(3): 193-202.

Obradović, S., Fedajev, A., \& Nikolić, Đ. (2012). Analysis of business environment using the multi-criteria approach - case of Balkan's transition economies. Serbian Journal of Management, 7 (1): 37 - 52.

Oliveira, F., Volpi, N., \& Sanquetta, C. (2003). Goal programming in a planning problem. Applied Mathematics and Computation, 140: 165-178.

Regan, P.J., \& Holtzman, S. (1995). R\&D decision advisor: An interactive approach to normative decision system model construction. European Journal of Operational Research, 84(1): 116-133.

Remer, D., Stokdyk, S., \& Van Driel, M. (1993). Survey of project evaluation techniques currently used in industry. International Journal of Production Economics, 32: 103-115.

Saaty, T.L. (1977). A scaling method for priorities in hierarchical structures. Journal of Mathematical Psychology, 15 (3): 234281.

Santhanam, R., \& Kyparisis, J. (1995). A Multiple Criteria Decision Model for Information System Project Selection. Computers and Operations Research, 22(8): 807-818.

Simanauskas, L., \& Sidlauskas, S. (2006). Resumptive evaluation of investment project efficiency. Ekonomika, 75: 91-104.

Tzeng, G-H., \& Teng, J-Y. (1993). Transportation investment project selection with fuzzy multiobjectives. Transportation Planning and Technology, 17(2): 91-112.

Tzeng, G-H., \& Teng, J-Y. (1998). Transportation investment project selection using fuzzy multiobjectives programming. Fuzzy Sets and Systems, 96(3): 259-280.

Ustinovichius, L., Zavadskas, E.K., \& Podvezko, V. (2007). Application of a quantitative multiple criteria decision making (MCDM-1) approach to the analysis of investments in construction. Control and Cybernetics, 36(1): 251-268. 
Vilutiene, T., \& Zavadskas, E.K. (2003). The application of multi-criteria analysis to decision support for the facility management of a city's residential district. Journal of Civil Engineering and Management, 10(4): 241-252.

Viteikiene, M., \& Zavadskas, E.K. (2007). Evaluating the sustainability of Vilnius city residential areas. Journal of civil engineering and management, 13(2): 149155.

Weingartner, H.M. (1966). Criteria for programming investment project selection. The Journal of Industrial Economics, 15(1): 65-76.

Wong, E.T.T., Norman, G., \& Flanagan, R. (2000). A fuzzy stochastic technique for project selection. Construction Management and Economics, 18(4): 407-414.

Zavadskas, E.K., \& Turskis, Z. (2008a.) A new logarithmic normalization method in games theory. Informatica, 19 (2): 303-314.

Zavadskas, E.K., Kaklauskas, A., \& Kvederyte, N. (2001). Multivariant design and multiple criteria analysis of building life cycle. Informatica, 12(1): 169-188.

Zavadskas, E.K., Kaklauskas, A., Banaitis, A., \& Kvederyte, N. (2004). Housing credit access model: The case for Lithuania. European Journal of Operational Research, 155(2): 335-352.

Zavadskas, E.K., Kaklauskas, A., \& Sarka, V. (1994). The new method of multicriteria complex proportional assessment of projects. Technological and Economic Development of Economy, 1(3): 131-139.

Zavadskas, E.K., Kaklauskas, A., Turskis, Z., \& Tamosaitiene, J. (2008b). Selection of the effective dwelling house walls applying attributes determined in intervals. Journal of Civil Engineering and Management, 14(2): 85-93.

Zavadskas, E.K., Kaklauskas, A., Turskis,
Z., \& Tamosaitiene, J. (2009). Multi-attribute decision making model by applying grey numbers. Informatica, 20(2): 305-320.

Zavadskas, E.K., Turskis, Z., Tamosaitiene, J., \& Marina, V. (2008c). Multi-criteria selection of project managers by applying grey criteria. Technological and Economic Development of Economy, 14(4): 462-477.

Zavadskas, E.K., Turskis, Z., Tamosaitiene, J., \& Marina, V. (2008d). Selection of construction project managers by applying COPRAS-G method. Computer Modelling and New Technologies, 12(3): 2228.

Zavadskas, E.K., Vilutiene, T., Turskis Z., \& Tamosaitiene, J. (2010). Contractor selection for construction works by applying SAW-G and TOPSIS grey techniques. Journal of Business Economics and Management, 11(1): 34-55.

Zwikael, O., \& Smyrk, J.R. (2011). Project management for the creation of Organisational value. London: Springer.

Zwikael, O., \& Smyrk, J. (2012). A general framework for gauging the performance of initiatives to enhance organizational value. British Journal of Management, 23: 6-22. 